\title{
Analysis of Physical Conditions of Aerobic Endurance or VO2Max
}

\author{
Akhmad Amirudin \\ Physical Education Study Program \\ Department of Sport and Health Education \\ akhmad.amirudin@ulm.ac.id
}

\author{
Said Abdillah \\ Physical Education Study Program \\ Department of Sport and Health Education \\ Said.abdillah@ulm.ac.id
}

\begin{abstract}
The purpose of this study was to determine the physical condition of aerobic endurance or VO2Max football players of JPOK FKIP ULM Banjarbaru. This research employed descriptive research. The samples for the study were 20 samples taken using total sampling techniques. This study used the MFT instrument or bleep test conducted in one meeting. The results of data analysis using descriptive statistics (frequency tabulation) revealed that the percentage of physical condition results of aerobic endurance or VO2Max JPOK football players of FKIP ULM Banjarbaru is included in the excellent category as many as 2 people by $10 \%$, which included in the good category were 18 people by $90 \%$. It was concluded that the physical condition of aerobic endurance or VO2Max football players of JPOK FKIP ULM Banjarbaru is included in both categories $(B)$.
\end{abstract}

Keywords: physical conditions, aerobic endurance, football players

\section{INTRODUCTION}

Sport is a part of human daily activities which is useful for forming a healthy body and spirit. Until now, sport has made a positive and tangible contribution to improving public health. In addition, sport also plays a role in increasing the ability of the nation in implementing a sustainable development system.

According to the Republic of Indonesia Law No. 3 of 2005 concerning the National institutional system Chapter 1 article 1 paragraph 13, "Performance sports are sports that foster and develop sportsman in a planned, tiered and sustainable manner through competence to achieve high achievements with the support of sports science and technology." In accordance with the notion of achievement sports mentioned above, achievement sports are sports of coaching and developing potential in a person which is carried out in a planned, tiered and competent manner with the aim of achieving high achievements.

Football players must also have a good physical condition so that they are able to do sports activities without experiencing excessive fatigue. On the contrary, if a football player has a physical condition that is not good, especially bad, then he will have difficulty in doing these sports activities, causing excessive fatigue. "General physical condition is a basic ability to develop the ability of the achievement of the body consisting of components of strength, speed, endurance and flexibility" [1]. A football player must master the basic techniques that are correct must also have good physical conditions. Physical conditions in football that are indispensable include strength, speed, flexibility, balance, coordination, agility, endurance, explosive power, accuracy and reaction [2]. One physical condition that is really needed by football players is the durability of vo2maks, Soccer players must have good endurance. Good endurance is needed in football games because players must play in normal time $2 \times 45$ minutes [3].

Football is a group or team sport. Football is a sport that is developed in the college or student environment. Through football, students gain a lot of benefits, especially in terms of good physical, mental and social growth. Their goal of playing football is basically the same, namely to get pleasure, get physical fitness and achieve optimal performance.

To achieve good performance is not easy, there are many factors that influence. These factors can be classified as follows: "Factors originating from within (internal) and from outside (external). Internal factors are factors that originate from the potential that exists in athletes or in other words, come from the ability of the athlete itself as a whole both regarding his physical abilities, techniques, tactics and by his mental abilities. While external factors are factors that can influence athletes' achievements from outside the athlete themselves such as facilities and infrastructure, coaches, coaches, sports teachers, families, funds, organization, climate, and nutritious food."

On the campus, FKIP ULM JPOK has the most and the best football players. It is because students who study not only gain education but also simultaneously train their hidden talents with the assistance of lecturers and coaches who are experts in the field of football. It was proven that there were some matches either public or between universities, and the JPOK football team often won.

Based on observations made by the researchers on JPOK FKIP ULM football players took place during the final party match between JPOK against Uniska, in the Menpora trophy match, the appearance of JPOK players had declined. This condition was seen during the first round of Uniska's players successfully penetrating JPOK players' defenses so that Uniska's players managed to break through the JPOK goal. At the end of the second half, the Uniska Team players' performance was seen in a declining state such as inaccurate shooting, inaccurate passing, and decreased ball possession, but the Team from JPOK is still stable. Until the end of the round the JPOK Team can win the match.

Based on observations that occur in the field, the researchers suspect the physical condition (VO2Max) 
It is seen on Figure 2 that the aerobic endurance data of owned by JPOK players is stable and good. However, it needs to be proven scientifically, through a study entitled "Physical Condition Analysis (VO2Max) JPOK Football Player FKIP ULM Banjarbaru".

\section{METHOD}

The research method used in this research is descriptive method. Population is a group from which researchers gather information and to whom conclusions will be drawn. the study population included all JPOK FKIP ULM Banjarbaru football players as many as 20 players. The sample is part or representative of the population. In this study, the sample is as much as $100 \%$ of the total population. Therefore, this research is called population research with total sampling technique. This is for the following reasons: (1) So that research results can describe the actual situation on the ground; (2) The population is relatively small, allowing each member of the population to be sampled.

One of the tests that can be used to measure VO2Max is the Multi-Stage Run test or the Multi-Stage Fitness Test. The advantage of this test from other tests is that it has a high degree of accuracy, does not require expensive equipment, the procedure is simple, easy to implement and easy to interpret the test.

Multi-Stage Running or Multistage Fitness Test is a test conducted in the field, simple but produces a fairly accurate estimate of the maximum oxygen consumption for various purposes. Basically, this test is direct; the testi takers run back and forth along the track or track that has been measured before, while listening to a series of signs in the form of the sound "tut" recorded on the tape. To get data about the physical condition of the football player JPOK FKIP ULM Banjarbaru, the instrument used in this study was through the MFT test and measurement or Bleep test [4]. In accordance with the objectives and research questions raised, then testing the data that has been obtained will be analyzed using descriptive statistics (frequency tabulation) [5].

\section{RESULTS AND DISCUSSION}

This study aims to determine the physical condition of VO2Max or aerobic endurance JPOK Football Players FKIP ULM Banjarbaru, the intended physical condition is aerobic endurance. Aerobic endurance or vo2max is the capacity of the circulatory system (heart, blood vessels, and blood) and the respiratory system (lungs) to distribute oxygen to the muscles at work and transport waste from these muscles.

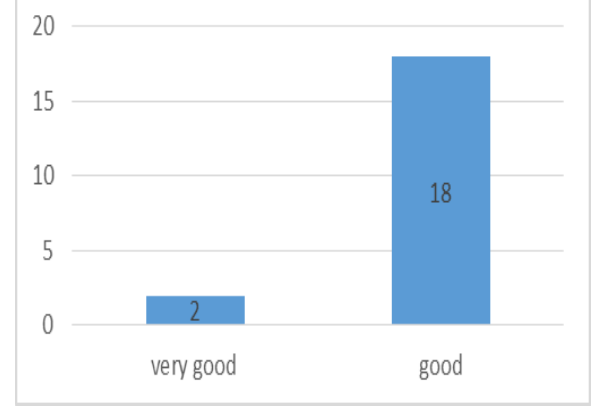

Fig. 1. The results of Vo2max Football Players JPOK FKIP ULM football players in the excellent rankings there are 2 people and in the good ranking as many as 18 people.

Based on the results of aerobic endurance variable data or VO2Max by performing MFT, it turns out that of the 20 football players JPOK FKIP ULM 2 people have aerobic endurance above the average score group, 18 people have aerobic endurance in the average score group. Many factors affect the aerobic endurance of JPOK FKIP ULM football players. Two people who have aerobic endurance above and the average score is due to routine exercise outside the specified schedule. Players who have a good level of endurance will be able to do well. Conversely, players who do not have good endurance then they will not be maximal in displaying their technical abilities and tactics.

The endurance abilities of the players can be improved by regular and programmed training through the endurance training method. Training methods that can be done in increasing endurance are such as the long duration method and the interval method. The long duration method has the characteristic absence of rest during loading and the running speed can be constant and can change. The principle method of intervals there is a time between (recovery interval) between loading one with the next loading [6]. While 18 players who have an average aerobic endurance because the training is only in accordance with the specified schedule.

This result shows that some of the JPOK FKIP ULM football players sampled in this study need to increase their aerobic endurance. "Endurance is the ability to work with a certain intensity in a long period of time, without excessive fatigue" [7]. If the aerobic endurance of JPOK FKIP ULM football players is in very good condition, the players can last longer and can improve the quality of their performances in the game $2 \times 45$ minutes. For this reason, training programs on physical conditions must be systematically improved so that they become better and the physical condition is well maintained.

\section{CONCLUSION}

Based on the findings of the study on the physical condition of aerobic endurance or vo2max of JPOK FKIP ULM Banjarbaru football players, it can be concluded that the average VO2max possesses by JPOK FKIP ULM football players is 47.59 . Two people $(10 \%)$ are categorized very well and 18 people $(90 \%)$ are categorized as good. Overall physical condition (VO2Max) owned by JPOK FKIP ULM football players can be categorized as good.

\section{REFERENCES}

[1] Syafruddin, Dasar-dasar Kepelatihan Olahraga, Padang: DIP Proyek UNP, 1999 .

[2] I. Imanudin, Sports Coaching, Bandung: Indonesian Education University, 2008.

[3] O. Maliki, H. Hadi and I. F. Royana, "Analisis Kondisi Fisik Pemain Sepak Bola Klub Persepu UPGRIS Tahun 2016,” Jendela Olahraga, 2017.

[4] Ismaryati, Sports tests and measurements, Surakarta: Eleven University in March, 2008. 
[5] N. Sigit, Respiratory Therapy in Asthma Sufferers, Yogyakarta: Faculty of Science Sports, Yogyakarta University, 2008.

[6] H. Irawadi, Physical Conditions and Measurements, Padang: FIP UNP, 2011.

[7] F. Albertus and M. M. Faruq, Tes dan Pengukuran dalam Olahraga, Yogyakarta: CV. Andi Offset, 2014. 